\title{
Microscopic analysis and microstructural characterization of the organic and inorganic components of dairy fouling during the cleaning process
}

\author{
Alfons Eduard Guerrero-Navarro, ${ }^{1}$ Abel Guillermo Ríos-Castillo, ${ }^{1} \odot$ Carolina Ripolles-Avila, ${ }^{1}$ Xavier Felipe, ${ }^{2}$ \\ and José Juan Rodríguez-Jerez ${ }^{1 *}$ (D) \\ ${ }^{1}$ Food Hygiene Unit, Veterinary Faculty, Universitat Autònoma de Barcelona, Travessera dels Turons s/n, Cerdanyola del Vallès, 08193, Spain \\ ${ }^{2}$ Institute of Agricultural-Alimentary Research and Technology-Monells, Finca Camps i Armet, Monells, 17121, Spain
}

\begin{abstract}
This study evaluated the organic residues of milk fouling using fluorescence and confocal laser scanning microscopy. The inorganic content was analyzed with energy-dispersive X-ray spectroscopy, complemented with inductively coupled plasma optical emission spectrometry. These techniques were applied to evaluate milk fouling cleanliness using an alkaline product and an enzymatic formulation based on protease and amylase. The results showed that the efficiency of enzymatic cleaning was $87.1 \%$ when it was evaluated at $55^{\circ} \mathrm{C}$ for 30 min, and with a medium of $\mathrm{pH}$ 8.5. No difference was found from the efficacy in eliminating dairy fouling observed for the chemical cleaning (86.9\%). The fluorescence microscopy proved useful for determining the organic solid components in the outer layer of the dairy fouling. The fouling spatial disposition in 3 dimensions, obtained by confocal laser scanning microscopy, showed that it was formed of $51.3 \%$ sugars, $9.3 \%$ fats, and $39.4 \%$ proteins, with the enzymatic cleaning of these compounds being homogeneous, compared with chemical cleaning. The protein and lipid contents were in the surface layer, whereas sugars were located in the innermost part that contributes to the Maillard reaction during fouling formation. After enzymatic cleaning, the reduction in the concentration of $\mathrm{Ca}$ and $\mathrm{P}$ was 71.61 and $74.67 \%$, respectively, compared with fouling intact. Thus, enzymatic cleaning, without the accumulation of $\mathrm{Na}$ from chemical cleaning, leaves 1.5 times less mineral than chemical cleaning. Knowing the content and structure of fouling in the industry helps to formulate better products to achieve proper levels of cleanliness. Additionally, studying the cleaning residues helps to avoid problems of cross-contamination between batches or subsequent microbial growths (biofilms) on surfaces with residues.
\end{abstract}

Received May 13, 2019.

Accepted November 13, 2019.

*Corresponding author: josejuan.rodriguez@uab.cat
Key words: milk fouling, microscopy, component, cleaning process, enzymatic product

\section{INTRODUCTION}

During heat treatments, materials from food are deposited on the surfaces of the facilities, which is known as fouling (Fryer and Asteriadou, 2009; Sadeghinezhad et al., 2015). The problems produced by fouling can be summarized into 3 different categories: food security, shelf life, and operating problems (Bansal and Chen, 2006; Barish and Goddard, 2013). This is important to avoid cross-contamination between different batches from preexisting fouling in the facilities (Hagsten et al., 2016; Ayala et al., 2017). While the cleaning process is costly and time consuming, it is essential to the food industry (Liu et al., 2006; Fryer et al., 2011; Ríos-Castillo et al., 2018). However, this process is still poorly understood and cleaning protocols are designed in a semi-empirical manner. In the food industry, $25 \%$ of operating time is spent on the cleaning process (Fryer et al., 2011) and it is impossible to know the extent and composition of fouling throughout the plant. Thus, the use of models to represent the fouling must be taken into account, perhaps through a stochastic rather than a purely deterministic approach (Fryer and Asteriadou, 2009). Fouling is formed by an adherence to the surface and cohesion between elements of the layer on the surface, and cleaning can result from either or both adhesive and cohesive detachment (Liu et al., 2006). The Maillard reaction is considered one of the most important chemical reactions in food processing (Jaeger et al., 2010). It occurs when food products are processed at high temperatures, resulting in a browned appearance. This reaction also initiates adhesion of food to the surface by the presence of sugars and proteins, resulting in caramelization and, consequently, fouling formation (Huppertz and Gazi, 2016; Parisi and Luo, 2018). Therefore, identifying the fouling composition is a crucial step in studying the residues from industrial treatments to prevent their production and to under- 
stand how to better clean facilities. There is a wide range of options for identifying waste elements, and the choice depends on the kind of target identified: (1) whether the waste is attached to other items, (2) budget, (3) time available, and (4) access to new techniques or special requirements such as specialized personnel and additional safety features.

The 2 types of dairy fouling depend on the temperature of the process that promotes its formation. In type $\mathrm{A}$, the temperature range is 75 to $110^{\circ} \mathrm{C}$ and the composition is 50 to $70 \%$ proteins, 30 to $40 \%$ minerals, and 4 to $8 \%$ fat. Type B is formed at temperatures above $110^{\circ} \mathrm{C}$ and the content is 70 to $80 \%$ minerals, 15 to $20 \%$ proteins, and 4 to $8 \%$ fat (Visser and Jeurnink, 1997). This study used fouling type A, which is formed mainly by organic milk residues produced at $90^{\circ} \mathrm{C}$, similar to a pasteurization process (Bansal and Chen, 2006). However, the morphology and spatial composition are very heterogeneous in both types. A fluorescence microscope is widely used to study the structure and composition of foods and residues because this method enables the use of selective stains that binds to a variety of targets as proteins, fats, sugars, or minerals, as well as postprocesses (Auty et al., 2001). Likewise, confocal laser scanning microscopy (CLSM) is a technology that is widely used to study food structure and composition because this method enables the use of a variety of selective stains and post-processes (Auty et al., 2001). Many studies have been conducted on food products using CLSM [e.g., the distribution of fat and proteins in mozzarella cheese and chocolate (Auty et al., 2001)], as well as the fat globules in milk and milk products (Evers et al., 2008). In other studies, this technology has been used to study the structure and composition of different residues, such as fouling on membrane filtration units (Doumèche et al., 2007; Stoica et al., 2018). Other authors have studied dairy fouling type A (Boyce et al., 2010) and type B by CLSM (Hagsten et al., 2016). Furthermore, this technique can be complemented with other methodologies, such as calculating the amount of $\mathrm{OM}$ or proteins with colorimetric methods (Boyce et al., 2010) or time of flight-secondary ion MS (Zouaghi et al., 2018). Other techniques, such as scanning electron microscopy (Hagsten et al., 2016) or coupled plasma optical emission spectrometry (ICP-OES), reveal the morphology and the inorganic fraction of food samples. Additional information can be obtained from dairy fouling through other complementary techniques, such as analysis with energy-dispersive X-ray spectroscopy (EDX; Hagsten et al., 2016). Studying the morphology and distribution of dairy fouling is essential to understanding the behavior of this type of waste in the industry, its implications for safety by being able to act as a reservoir of bacteria in the form of biofoulings or bio- films (Liu et al., 2017; González-Rivas et al., 2018), or their resistance to cleaning processes. Thus, the aim of our study was to improve the knowledge about fouling type A, especially its composition and microstructure, and to identify the composition of the residues from cleaning procedures. Residues were produced to compare the effectiveness of 2 different cleaning products (an alkaline commercial product and a novel enzymatic formula) using a laboratory-fouling model as a target for the cleaners.

\section{MATERIALS AND METHODS}

\section{Milk and Test Surfaces}

Bovine whole raw milk was used to form fouling for the tests. The milk was supplied refrigerated at $5^{\circ} \mathrm{C}$ by a dairy farm (Can Bordoi Farm, Sant Antoni de Vilamajor, Catalonia, Spain) on the same day of each test. The test surfaces to form fouling consisted of stainless steel discs (American Iron and Steel Institute type 316 grade $2 \mathrm{~B}$ ), all with a diameter of $2.0 \mathrm{~cm}$ and a thickness of $1.2 \mathrm{~mm}$ (Figure 1A). Stainless steel was selected because it is one of the primary materials for plate heat exchangers. Additionally, heat resistant aluminum foil tape (Ceys, L'Hospitalet de Llobregat, Spain) was used for the walls of the stainless steel discs to form cylindrical containers for the fouling formation. Each wall side of the containers was $6 \mathrm{~mm}$ high and $70 \mu \mathrm{m}$ thick (Figure 1B). Before the containers were used, they were cleaned and disinfected (Anonymous, 2015; Ríos-Castillo et al., 2017). Thereafter, they were kept in sealed bags to avoid contamination until the fouling tests.

\section{Fouling Production}

The milk fouling models (MFM) were formed according to the modified procedure referenced by Guerrero-Navarro et al. (2019). First, the containers were weighed using an analytical balance and then pre-heated at $90^{\circ} \mathrm{C}$ in a fan-assisted oven (IDL-FI-80, Labolan, Navarra, Spain). When the containers reached the working temperature (Figure 1B), $0.4 \mathrm{~mL}$ of whole raw milk was added and they were placed back in the oven for $30 \mathrm{~min}$. The milk was then dried and attached to the surface. Thereafter, another $0.4 \mathrm{~mL}$ of milk was added. The addition of milk and the drying process were repeated 5 times, after which the washing process was performed by introducing each MFM into plastic flasks with $4 \mathrm{~mL}$ of distilled water at $50^{\circ} \mathrm{C}$ and shaking them at 2,500 rpm for $50 \mathrm{~s}$ using a vortex mixer (REAX Top, Heidolph Instruments, Schwabach, Germany). The containers were then rinsed with deionized water 


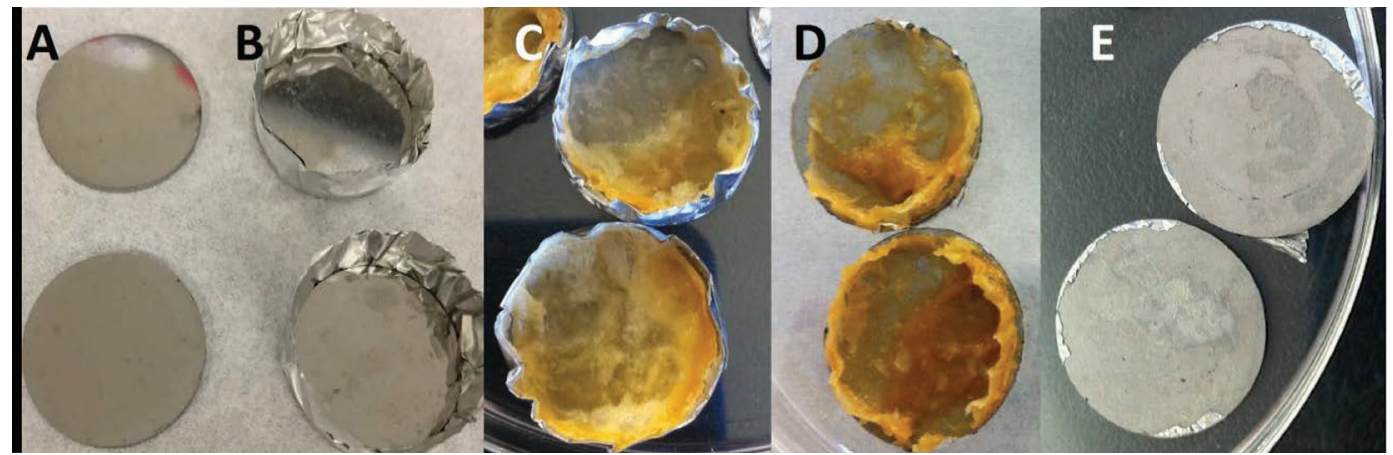

Figure 1. (A) Stainless steel American Iron and Steel Institute type 316 grade 2B discs $2 \mathrm{~cm}$ in diameter, (B) surfaces where the milk fouling models (MFM) were to be created, (C) MFM once the production process was finished, (D) MFM finished without aluminum walls, and (E) MFM once cleaned by the enzymes.

to remove the unattached milk on the surfaces and then pre-heated again at $90^{\circ} \mathrm{C}$ for $5 \mathrm{~min}$. Once the working temperature was reached, 5 additional steps of adding milk and drying were performed (10 cycles in total), after which the washing step was repeated using water at $50^{\circ} \mathrm{C}$ (Figure $1 \mathrm{C}$ ).

\section{Cleaning Solutions}

Two kinds of cleaning products were selected: a commercial solution (CS1) and an enzymatic solution (CS2). The CS1 solution was composed of $6 \% \mathrm{vol} / \mathrm{vol}$ of alkaline cleaner in deionized water (Brio Complex, Itram Higiene, Vic, Spain) and used at $70^{\circ} \mathrm{C}$ for 45 min with a $\mathrm{pH}$ of 10 to 12 according to the manufacturer's instructions. The CS2 solution was composed of $0.12 \%$ protease (Savinase, Novozymes, Bagsværd, Denmark), $0.10 \% \mathrm{vol} / \mathrm{vol}$ of amylase (Termamyl Ultra, Novozymes), and a non-foam surfactant (Tensio CIP, ITRAM Higiene). The CS2 was diluted in a buffer solution with a $\mathrm{pH}$ of 8.5 and used at $55^{\circ} \mathrm{C}$ for $30 \mathrm{~min}$.

\section{Improving the Enzymatic Formulation}

To improve the activity of the enzymatic formulation, 3 kinds of buffer solutions were evaluated. (1) Borate buffered saline (BBS; Sigma-Aldrich, Madrid, Spain) tablets were ready to use, prepared according to the manufacturer's instructions, and adjusted to $\mathrm{pH}$ 8.2. (2) Carbonate-bicarbonate buffer (CBB) capsules were ready to use. One capsule was added and homogenized in $100 \mathrm{~mL}$ of deionized water with a $\mathrm{pH}$ of 9.6. Then, the solution was diluted at a proportion of $1 / 16$ until a $\mathrm{pH}$ of 8.45 was reached. (3) Borate buffer hydrochloric acid (BB-HCl) consisted of a mixture of 2 solutions: solution 1 , sodium tetraborate $\left(\mathrm{Na}_{2} \mathrm{~B}_{4} \mathrm{O}_{7} ; 0.05 \mathrm{~mol} / \mathrm{L}\right)$, and solution 2, hydrochloric acid $(\mathrm{HCl}), 0.1 \mathrm{~N}$. To achieve a BB-HCl buffer of $\mathrm{pH} 8.5,65.25 \mathrm{~mL}$ of solution 1 was required, placed in a $100-\mathrm{mL}$ volumetric flask, and then filled to $100 \mathrm{~mL}$ with solution 2 .

\section{Testing the Buffer Solutions}

The 3 buffer solutions were tested under similar conditions and the $\mathrm{pH}$ of each one was measured at $20^{\circ} \mathrm{C}$ before the tests. The solutions in closed containers were then immersed in a water bath at $55^{\circ} \mathrm{C}$ (Unitronic 6320100, J.P Selecta S.A, Abrera, Spain) and the pH was measured at $30 \mathrm{~min}$ and $1 \mathrm{~h}$. The solutions were tempered at room temperature and $2.5 \mathrm{~h}$ after starting the experiments, the $\mathrm{pH}$ was measured again. Additionally, tap water was used to evaluate the maximum dilution of activity of the enzymatic solution and to establish its real-life economic cost. All the buffer solutions were repeatedly diluted in $1 / 2$ the volume of water until reaching $1 / 64$, and the $\mathrm{pH}$ measurements were made at room temperature.

\section{Cleaning Protocol}

The procedure of the cleaning protocol used to test the enzymatic formulation and the commercial product was based on previous research carried out by Guerrero-Navarro et al. (2019), with modifications made in the rescaling of the volumes of milk fouling adhered to surfaces. The enzymatic cleaning solutions were concentrated 10-fold, stored in sterile tubes, and frozen at $-18^{\circ} \mathrm{C}$ until use. Before the cleaning protocol, $5 \mathrm{~mL}$ of enzymatic cleaning solution was thawed at room temperature and diluted in $30 \mathrm{~mL}$ of buffer solution to obtain a test volume of $35 \mathrm{~mL}$. The cleaning solution was placed in a 50-mL plastic flask with the MFM. The plastic flask was then placed in a water bath at maximum agitation (Unitronic 320 OR, J.P Selecta S.A) at 
55 and $70^{\circ} \mathrm{C}$ for the enzymatic and chemical protocols, respectively.

The enzymatic cleaning protocol lasted $30 \mathrm{~min}$ and was split into 2 steps. First, the plastic flasks were placed at $55^{\circ} \mathrm{C}$ in the stirred water bath for $15 \mathrm{~min}$. Then, the MFM were removed from the cleaning solution and placed in new plastic flasks with $5 \mathrm{~mL}$ of deionized water at $50^{\circ} \mathrm{C}$. Using a vortex at $2,500 \mathrm{rpm}$ for $50 \mathrm{~s}$, the detachment elements were removed to simulate the flow of liquid in the pipes of the facilities. The containers were again placed in the cleaning solution and then stirred in a water bath for an additional $15 \mathrm{~min}$ at $55^{\circ} \mathrm{C}$. Last, the coupons were washed with hot water and stirred for $50 \mathrm{~s}$ to complete the enzymatic cleaning.

The procedure for the chemical cleaning protocol was carried out in the same way; however, these lasted for $45 \mathrm{~min}$ in three 15 -min steps at $70^{\circ} \mathrm{C}$ in a water bath at maximum agitation. After each 15-min step in the water bath, a washing step was performed in the same manner as the enzymatic cleaning protocol. The cleaned models were then left at room temperature and the fouling of the remaining milk products in the model was weighed once it had completely dried. The following techniques were applied to characterize the residue from different cleaning protocols in the same way as the untreated MFM.

\section{Methods to Study Dairy Fouling After the Cleaning Protocols}

The methods used to evaluate the characterization of the dairy fouling totaled 7: (1) A scanning electron microscope (EVO MA 10, Carl Zeiss, Oberkochen, Germany) with a maximum magnification of $1,000 \times$ was used to test the fouling morphology. (2) The fouling topography was analyzed with an optical confocal microscope (DCM 3D, Leica Microsystems, Bensheim, Germany) and the roughness of the samples was evaluated using Leica Map Premium software (version 6.2.6409). (3) The organic milk fraction of raw milk was determined using the near-infrared spectroscopy (NIRS) model NIR 5000 (FOSS-NIRSystems, Silver Springs, MD). The results were compared with an in- ternal calibration obtained from comparing the sample results and a standard of bovine whole milk. (4) The solid organic components of the fouling, both before and after the cleaning protocol, were determined using a fluorescence microscope (BX51, Olympus Optical, Tokyo, Japan). A combination of 3 different dyes (Table 1) was selected to dye the milk fouling samples at the same time. The stained samples remained in dark conditions for $25 \mathrm{~min}$. For each sample, the dyes were mixed in $60 \mu \mathrm{L}$ of sodium bicarbonate $\left(\mathrm{NaHCO}_{3}\right)$ $0.1 M$ to avoid the dimerization of concanavalin A. (5) The CLSM (TCS SP5, Leica Microsystems) was used to study the spatial composition of the MFM microstructure. The Imaris 5.7 software (Bitplane, Zurich, Switzerland) was used to create the fouling 3-dimensional images. The microstructures were analyzed with an inverted $10 \times$ objective using fluorescent dyes (Table 1 ), whereas samples that were previously incubated in a humidity chamber for $15 \mathrm{~h}$ were then placed in cell culture capsules ( $\mu$-Dishes IBIDI, GmbH, Planegg, Austria). (6) The EDX (INCAx-act detector, Oxford Instruments plc., Tubney Woods, UK), coupled with a scanning electron microscope, was used to quantify or qualitatively identify the elements of the stainless steel disc surfaces to evaluate their possible effect on the fouling formation. (7) The ICP-OES (Optima 4300DV, Perkin-Elmer, Waltham, MA), subject to acidic digestion with nitric acid $\left(\mathrm{HNO}_{3}\right)$ in a microwave digester, was used to analyze the inorganic fraction of bovine whole milk, the laboratory model of dairy fouling, and the residues of the cleaning protocols. For this, the solid samples were boiled in nitric acid for $30 \mathrm{~min}$ and the liquid fraction was filtered by Milli-Q, with a pore size of $0.45 \mu \mathrm{m}$ (Millipore GmbH, Schwalbach, Germany). The amounts of $\mathrm{Ca}, \mathrm{K}, \mathrm{Na}, \mathrm{Mg}$, and $\mathrm{P}$ were measured with this technique.

\section{Statistical Processing of Data}

The efficiency of the enzymatic treatment and the chemical product were compared using the independent Student's t-test, as well as software R version 3.1.0 (R Development Core Team, Vienna, Austria). A value of $P<0.05$ was considered statistically significant.

Table 1. Dyes used in fluorescence and confocal laser scanning microscopy

\begin{tabular}{|c|c|c|c|c|c|}
\hline Fluorescent dye & Produced by ${ }^{1}$ & $\begin{array}{l}\text { Concentration } \\
(\mathrm{mg} / \mathrm{mL})\end{array}$ & $\begin{array}{c}\text { Volume } \\
\text { used }(\mu \mathrm{L})\end{array}$ & Target & Color \\
\hline Fluorescein 5-isothiocyanate & Sigma-Aldrich & 1.0 & 10.0 & Proteins & Green \\
\hline Nile Red & Sigma-Aldrich & 0.1 & 10.0 & Lipids & Red \\
\hline $\begin{array}{l}\text { Concanavalin A-Alexa Fluor } 350 \\
\text { (ConA-350) }\end{array}$ & Thermo Fisher Scientific & 0.3 & 20.0 & Sugars & Blue \\
\hline
\end{tabular}

${ }^{1}$ Sigma-Aldrich (Madrid, Spain), Thermo Fisher Scientific (Waltham, MA). 


\section{RESULTS AND DISCUSSION}

\section{Fouling Formation}

The results of milk composition for fouling formation showed a TS composition of $12.64 \%$, of which $3.63 \%$ were lipids, $3.38 \%$ proteins, and $5.63 \%$ sugars (Table 2 ). These results were obtained using 10 batches of milk, which were analyzed using NIRS methodology in triplicate. The predicted composition of the milk used for this study agreed with the data found by Bylund (1995) about the average composition of this type of food product. Once the fouling production was performed using milk with a standard composition, it obtained a mean fouling weight of $44.56 \mathrm{mg} / \mathrm{cm}^{2}$, higher than that previously obtained in other studies (Figure 1D). Liu et al. (2017) obtained $19.21 \mathrm{mg} / \mathrm{cm}^{2}$ of fouling by using raw milk on stainless steel (316 L) with the objective of evaluating fouling behavior and bacterial adhesion during the pasteurization of milk. Further, Zouaghi et al. (2018) obtained $30.8 \mathrm{mg} / \mathrm{cm}^{2}$ of fouling with a solution of whey protein that formed on native stainless steel under industrial processing conditions. Therefore, it can be assumed that our experiments carried out with raw cow milk to produce dairy fouling are a correct simulation of a real fouling situation in the industry, given that the milk contained a standard composition. From the stock of the fouling formed, 20 batches were used for chemical cleaning tests and an additional 20 were used for tests with the enzymatic formula.

\section{Buffer Solutions}

To improve enzymatic cleaning, before performing the cleaning tests, selected buffer products were evaluated. The results showed that the $\mathrm{BBS}, \mathrm{CBB}$, and $\mathrm{BB}-\mathrm{HCl}$ buffer solutions were quite stable over time, temperature, and concentration variations. In this sense, Figure 2 shows the evolution in the behavior of the $\mathrm{pH}$ curves of the solutions, where the slopes are flat, indicating a reduced variation in the action of the buffers at different temperatures (between 20 and $55^{\circ} \mathrm{C}$ ) and time (up to $2.5 \mathrm{~h}$ ). On the contrary, the control curve showed $\mathrm{pH}$ differences related to environmental variations. The $\mathrm{pH}$ measurement using different buffer concentrations at $20^{\circ} \mathrm{C}$ (Figure 3) showed a drop in the $\mathrm{pH}$ of the $\mathrm{CBB}$ buffer when the concentration decreased by more than $25 \%$. This implies that it keeps the $\mathrm{pH}$ stable as long as no substantial dilution occurs. However, in our study, it was not stable enough to keep the $\mathrm{pH}$ in a dynamic fouling cleaning environment using enzymatic formulations. However, the results for boron-based buffers were more efficient, as the BBS buffer was stable when maintaining a $\mathrm{pH}$ between 8 and 8.5 during all dilutions,

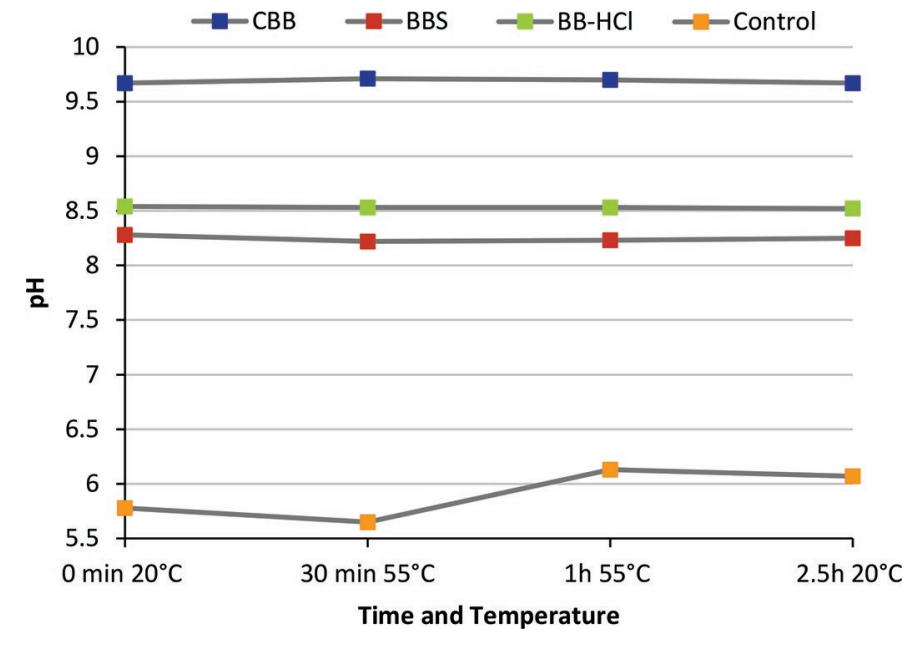

Figure 2. Average $\mathrm{pH}$ of different buffer solutions exposed to heat over time, with tap water as a control. $\mathrm{CBB}=$ carbonate-bicarbonate buffer; $\mathrm{BBS}=$ borate buffered saline; $\mathrm{BB}-\mathrm{HCl}=$ borate buffer hydrochloric acid.

whereas the $\mathrm{BB}-\mathrm{HCl}$ buffer kept the $\mathrm{pH}$ stable with a variation of \pm 0.15 over successive dilutions. From these data, the buffer solution based on $\mathrm{BB}-\mathrm{HCl}$ was selected as the most balanced buffer because the borate buffer stabilizes the $\mathrm{pH}$ during the various steps. Once the borate buffer was selected, all the following cleaning tests with enzymes were carried out with undiluted $\mathrm{BB}-\mathrm{HCl}$ and deionized water.

\section{Cleaning Efficacy}

According to the results of the cleaning procedure, the chemical cleaning efficiency of the fouling was $86.9 \%$ when it was performed for $45 \mathrm{~min}$ at $70^{\circ} \mathrm{C}$ with a $\mathrm{pH}$ of 10 to 12 . In the case of enzymatic cleaning, its efficiency was $87.1 \%$ when tested for $30 \mathrm{~min}$ at $50^{\circ} \mathrm{C}$ with a $\mathrm{pH}$ of 8.5. These results show no statistically significant differences between the 2 treatments $(P>0.05$; Figure 4 ), whereas they were observed to be equally efficient in terms of the removal of scale (Figure 1E). The results of the enzymatic cleaning differed from those observed by Guerrero-Navarro et al. (2019), who noted that the enzymatic efficiency for cleaning dairy fouling was $78 \%$

Table 2. Milk composition used for the fouling generation $(\mathrm{n}=30)$; composition was determined by near-infrared reflectance spectroscopy

\begin{tabular}{lc}
\hline Component & Average $(\% \pm \mathrm{SD})$ \\
\hline Lipids & $3.63 \pm 0.14$ \\
Proteins & $3.38 \pm 0.10$ \\
Total sugars & $5.63 \pm 0.19$ \\
TS & $12.64 \pm 0.19$ \\
\hline
\end{tabular}




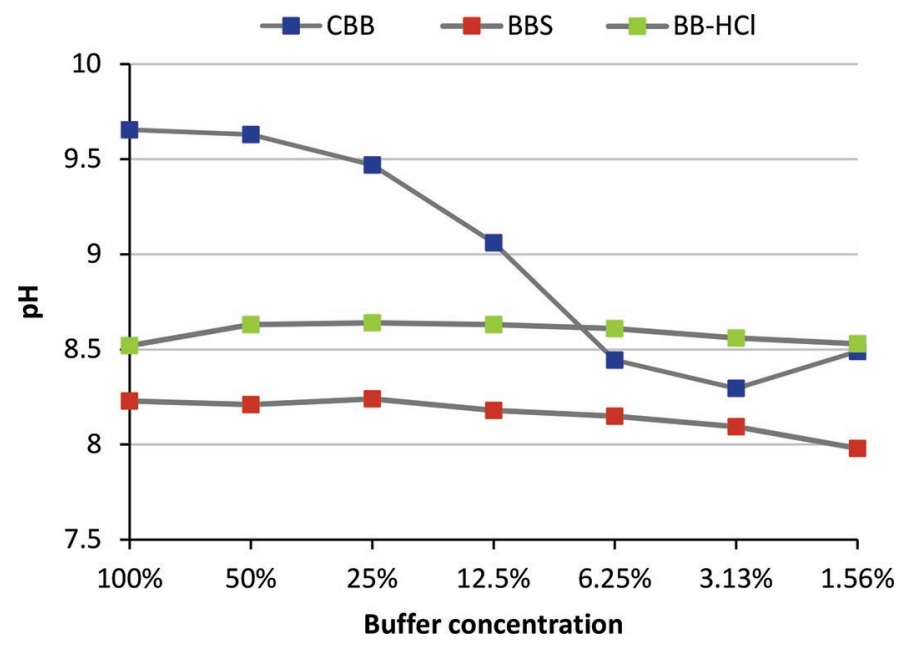

Figure 3. $\mathrm{pH}$ of diluted buffer solutions using tap water at $20^{\circ} \mathrm{C}$. $\mathrm{CBB}=$ carbonate-bicarbonate buffer; $\mathrm{BBS}=$ borate buffered saline; $\mathrm{BB}-\mathrm{HCl}=$ borate buffer hydrochloric acid.

under the same conditions of time and temperature as in our study. Thus, the increase in efficiency in our study may be due to the fact that the fouling production procedure was modified, optimizing its production, whereas the $\mathrm{pH}$ during cleaning was reduced from 9.5 to 8.5 using the $\mathrm{BB}-\mathrm{HCl}$ buffer. With an efficiency value above $87 \%$ of dairy fouling, enzymatic cleaning procedures can be suggested as a feasible alternative to the use of chemical cleaners, which have the added benefit of reduced waste water, cleaning times, and energy saving on thermal procedures (Fryer and Asteriadou, 2009; Boyce et al., 2010).

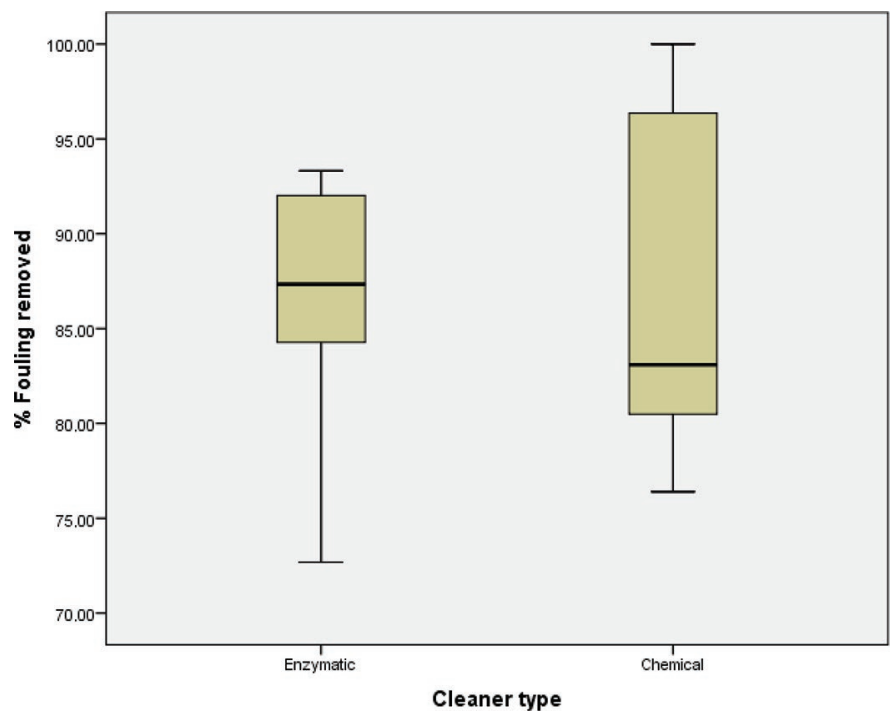

Figure 4. Boxplot of the efficiency of 2 different cleaners $(n=27)$. Black lines represent the median, boxes represent the dispersion of the results obtained, and whiskers represent the SD.

\section{Morphology and Microstructure}

The results of the scanning electron microscopy technique showed that 2 types of materials form the micro-morphology of the fouling model. These results are based on their density and resistance to the passage through the electrons during this technique. Thus, one of them appears darker than the other (Figure 5B). This could be attributed to the presence of a higher concentration of mineral matter, which is denser than OM. In addition, fissures and pores are present on the surface (Figure 5A and 5B). These fissures in the morphology could be credited to the desiccation that occurs during the milk fouling formation. Other authors suggest that these pores could be produced by gas bubbles formed within the fouling during the heat treatment (Boyce et al., 2010; Gandhi et al., 2017). Boyce et al. (2010) suggest that these bubbles can increase the formation of the scale. Moreover, in the dairy industry, liquids under pressure reduce the formation of air bubbles (Bansal and Chen, 2006). Additionally, roughness analysis (Figure $6 \mathrm{~A}$ and $6 \mathrm{~B}$ ) showed that the surface of the MFM using a 3-dimensional topography measurement and scanning electron microscope microphotography could produce cracks. However, the pores are of a natural origin due to the absence of a drying process to carry out this topographic technique.

\section{Organic Fouling Fraction}

Two different techniques, epifluorescence microscopy and CLSM, were used to evaluate the content of OM. The epifluorescence microscopy method using the fluorescein 5-isothiocyanate, Nile red, and concanavalin A-Alexa Fluor 350 (Table 1) was an easy procedure to detect the solid components of the dairy fouling and the residues of the cleaning protocol. However, when using this method, it is challenging to distinguish and identify fouling components because it only examines the external fouling layer (Figure 7A and 7B). This was probably due to the compounds produced by the Maillard reaction from the proteins and sugars in the milk (Bansal and Chen, 2006; Parisi and Luo, 2018). Moreover, this was especially true for the ConA-350 dye due to the amount of background auto-fluorescence in the blue channel. The CLSM was also used because this technique is very sensitive to detecting fluorescent dyes despite the samples being autofluorescent. Thus, the 3 dyes used were detected by this microscopy and used for the 2-dimensional models (Figure 7C, 7E, and $7 \mathrm{~F}$ ) and 3-dimensional models (Figure 7D), which were produced in MFM and the residues of cleaning protocols. The results were also obtained from the average intensity of the fluorescence in each channel to trace 

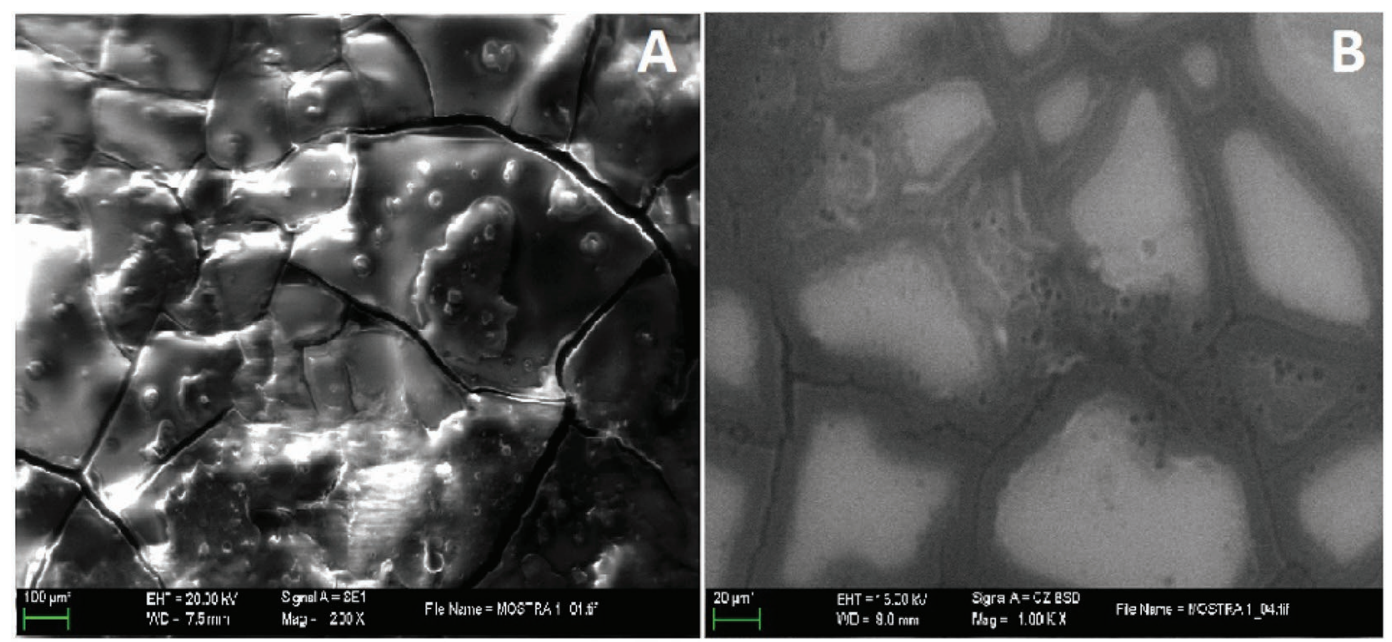

Figure 5. Microphotographs of milk fouling models using scanning electron microscopy. Amplifications: $(\mathrm{A}) 200 \times(\mathrm{scale}$ bar $=100 \mu \mathrm{m}),(\mathrm{B})$ $1,000 \times($ scale bar $=20 \mu \mathrm{m})$.

the abundance of each compound in the depth of the sample (Figure 8) and to quantify the organic compounds (Figure 9). The CLSM can record each channel in different files, a feature that is very useful when obtaining the spatial disposition of the different elements
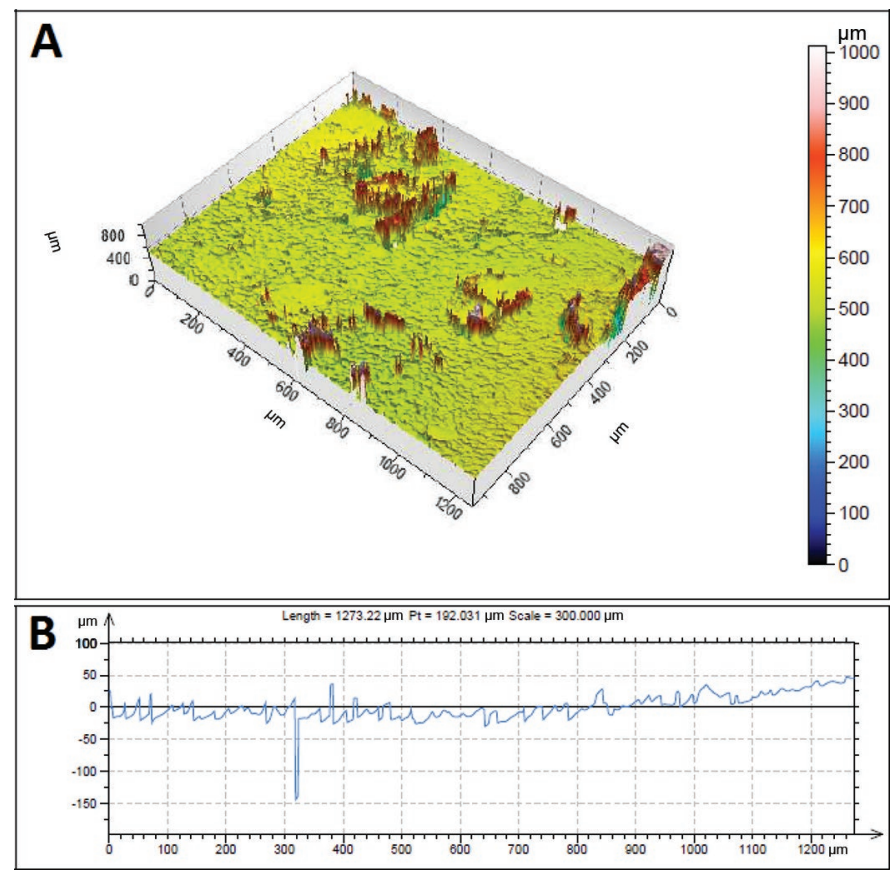

Figure 6. Topographic view of the milk fouling model. (A) Threedimensional view of the surface of the fouling model. Cold colors represent the depressions on the surface below the average level of the sample, whereas warm colors represent the elevations above the surface average. (B) Topographic profile of the milk-fouling model. Level 0 represents the average height of the surface; negative values are cracks and concavities, whereas positive values are undulations and accumulations above the average height. of samples (Farias et al., 2014; Gandhi et al., 2017). In this example of a dairy fouling model (Figure 7D), various overlapping channels are visible where there are different compounds. Figure $7 \mathrm{C}$ shows a green channel over a blue channel, which means that the proteins are on the surface and the sugars are in the innermost part. In regards to overlapping the 3 channels, red dots appear over all the other compounds (Figure $7 \mathrm{E}$ and $7 \mathrm{~F}$ ), meaning that the fats are in the highest part of the fouling model. By processing the image information with the MetaMorph software (Molecular Devices, Sunnyvale, CA), the differences in abundance at multiple depths of the fouling can be observed (Figure 8). At the top of the sample, there is a mixture of protein and fats (Figure $7 \mathrm{E}$ and 8), whereas sugars increase in intensity (Figure $7 \mathrm{C}$ and 8 ) in the middle of the sample. The quantification of the organic compounds in milk fouling using CLSM (Figure 9) showed that the fouling before cleaning treatments was formed of $51.3 \%$ sugars, $9.3 \%$ fats, and $39.4 \%$ proteins. After the cleaning treatments, it was observed that the chemical cleaning was not homogeneous, showing a reduction in sugars $(17.4 \%)$ and proteins $(27.9 \%)$ with an increase in the presence of fats $(54.7 \%)$ in the residual fouling. However, the enzymatic cleaning (51.1\% sugars, $10.0 \%$ fats, and $38.9 \%$ proteins) was homogeneous in terms of eliminating organic compounds. This is explained by the catalytic action of enzymes that degrade $\mathrm{OM}$ (Timmerman et al., 2016), with a temperature of $55^{\circ} \mathrm{C}$ (Graßhoff, 2002) with a pH of 8.5 tested in our study. Furthermore, the study of fouling morphology showed that the distribution of protein and lipid content in the outer part of the fouling and sugars in the innermost part explains the process of the Maillard reaction, 

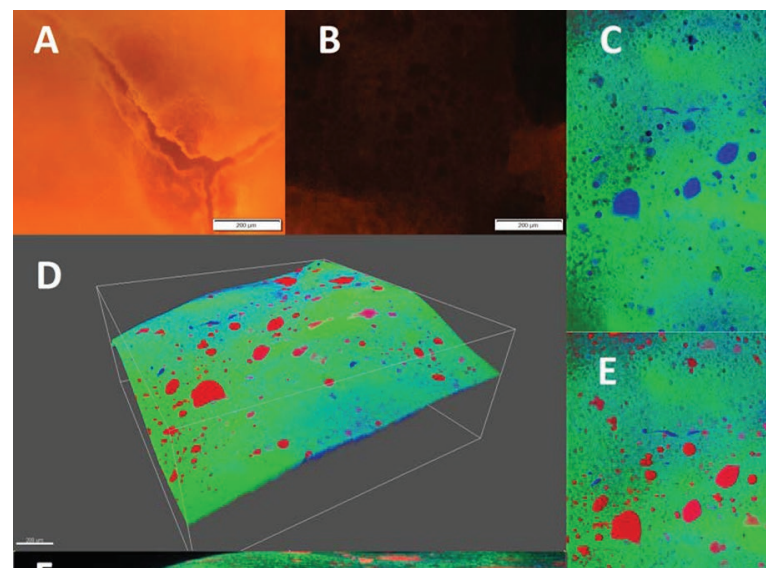

$\mathbf{F}$

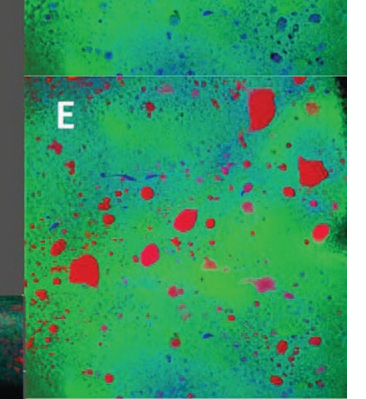

Figure 7. (A) Auto-fluorescence generated by milk fouling, $4 \times$ red/green filter, captured using fluorescence microscopy. (B) Autofluorescence after enzymatic cleaning. (C) Milk fouling dyed with selective fluorescence dyes, $10 \times$ channel blue (sugar/caramel) and green (protein) captured using confocal laser scanning microscopy (CLSM). (D) 3-Dimensional reconstruction using CLSM images of milk fouling with a height of $618.3 \mu \mathrm{m}$. (E) Milk fouling models dyed with selective fluorescence dyes, $10 \times$ channel blue, green, and red (fats) captured using CLSM. (F) Side view of the entire stack of microphotographs.

which is responsible for the start of the fouling adhesion in the presence of heat (Chiruta et al., 1997; Goode et al., 2013). In this sense, it has been observed that the fouling formed in the dairy industry tends to caramelize due to the presence of sugars (Newton et al., 2012).

\section{Inorganic Fouling Fraction}

The ICP-OES (quantification) and EDX coupled with scanning electron microscopy (qualification) were used to study the inorganic fraction. The results of the

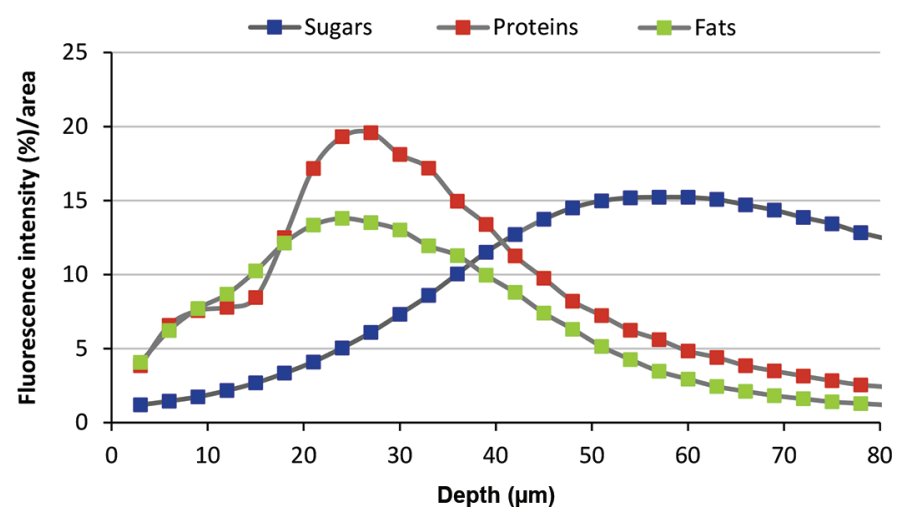

Figure 8. Representation of the intensity (\%) of the blue, red, and green confocal laser scanning microscopy (CLSM) channels from external layer $(0 \mu \mathrm{m})$ to the depth $(80 \mu \mathrm{m})$ of the milk fouling.
EDX-scanning electron microscopy (Figure 10) showed 3 different peak regions along the graph: (1) $\mathrm{Cr}$ and $\mathrm{Fe}$ peaks, which correspond to stainless steel as the base material for the production of milk fouling, (2) $\mathrm{C}$ and $\mathrm{O}$ peaks that correspond to $\mathrm{OM}$, and (3) the lower peaks that represent the mineral salts of the milk. However, when the peaks are less than 2 to $4 \%$, they cannot be used for quantification, though they do indicate the presence of these elements qualitatively. Gandhi et al. (2017) suggest that the presence of $\mathrm{C}$ and O peaks obtained with EDX indicate the presence of lipids, the peaks of $\mathrm{C}$ and $\mathrm{N}$ indicate the presence of proteins, whereas the S peak indicates the presence of sulfurcontaining AA. During the tests with scanning electron microscopy, an analysis was performed in parallel using EDX coupled with scanning electron microscopy (Figure 10) to identify the elements that would later be quantified by ICP-OES (Figure 11). These results showed that the highest mineral concentration in the whole milk was $\mathrm{K}(1.54 \mathrm{mg} / \mathrm{g})$, followed by Ca $(1.18$ $\mathrm{mg} / \mathrm{g})$ and $\mathrm{P}(0.87 \mathrm{mg} / \mathrm{g})$. However, the most significant mineral on the fouling was Ca $(14.83 \mathrm{mg} / \mathrm{g})$, followed by $\mathrm{P}(9.79 \mathrm{mg} / \mathrm{g})$ and $\mathrm{K}(7.39 \mathrm{mg} / \mathrm{g})$. The most crucial mineral component formed in milk is $\mathrm{Ca}_{3}\left(\mathrm{PO}_{4}\right)_{2}$ (calcium phosphate). Calcium and phosphates are not expected to form particles; however, the presence of proteins associates them. Consequently, in milk, $\mathrm{Ca}_{3}\left(\mathrm{PO}_{4}\right)_{2}$ precipitates together with milk proteins,

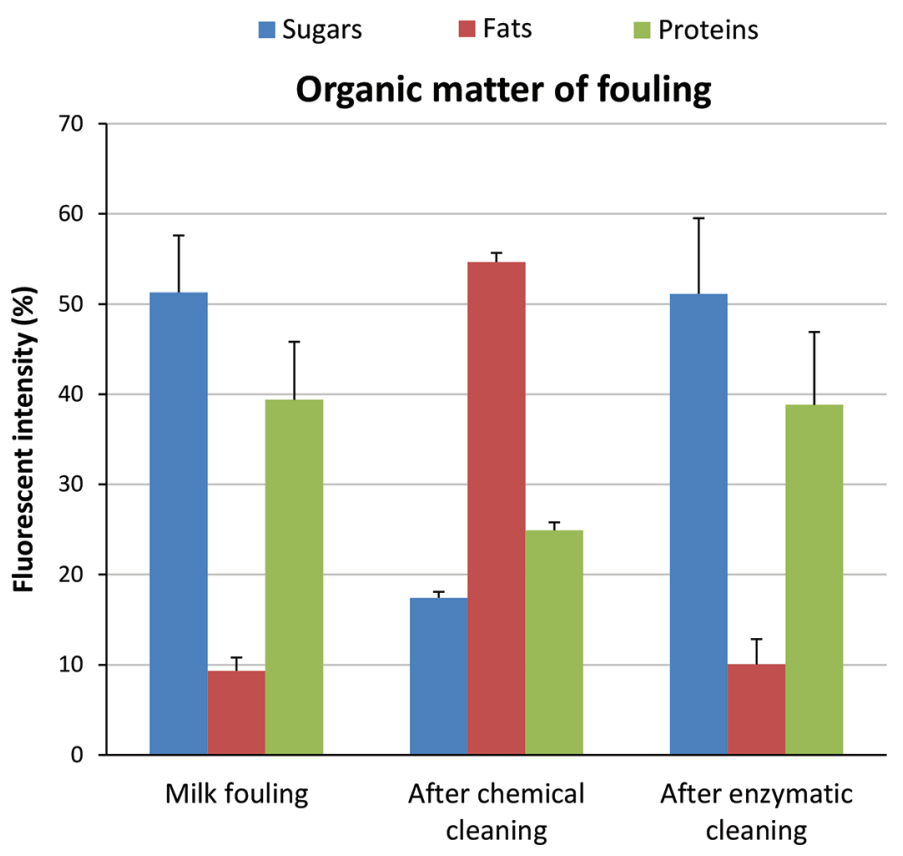

Figure 9. Fluorescent intensity (\%) in the OM from milk fouling models obtained by confocal laser scanning microscopy $(n=10)$. Error bars indicate SD. 
mainly whey proteins. In addition, the presence of $\mathrm{Ca}$ is essential for the growth of layers of protein deposits. The presence of positively charged Ca ions means an electrostatic repulsion, and therefore the formation of aggregates when heating the proteins (Amjad, 1998; Rosmaninho and Melo, 2006; Zhang and Ding, 2015). Therefore, a mineralization of the $\mathrm{OM}$ on the fouling was expected (Bansal and Chen, 2006). When an alkaline-acidic cleaning process was performed, Ca was reduced by $77.34 \%$, which was similar to $\mathrm{P}(75.08 \%)$. Furthermore, K was solubilized completely, whereas Na increased more than 3 -fold (340.91\%). The Na increased due to the solubilization of the ion from the chemical used on the fouling, while on the other hand, when the enzymatic treatment was performed, reductions in $\mathrm{Ca}$ and $\mathrm{P}$ concentrations of 71.61 and $74.67 \%$ were

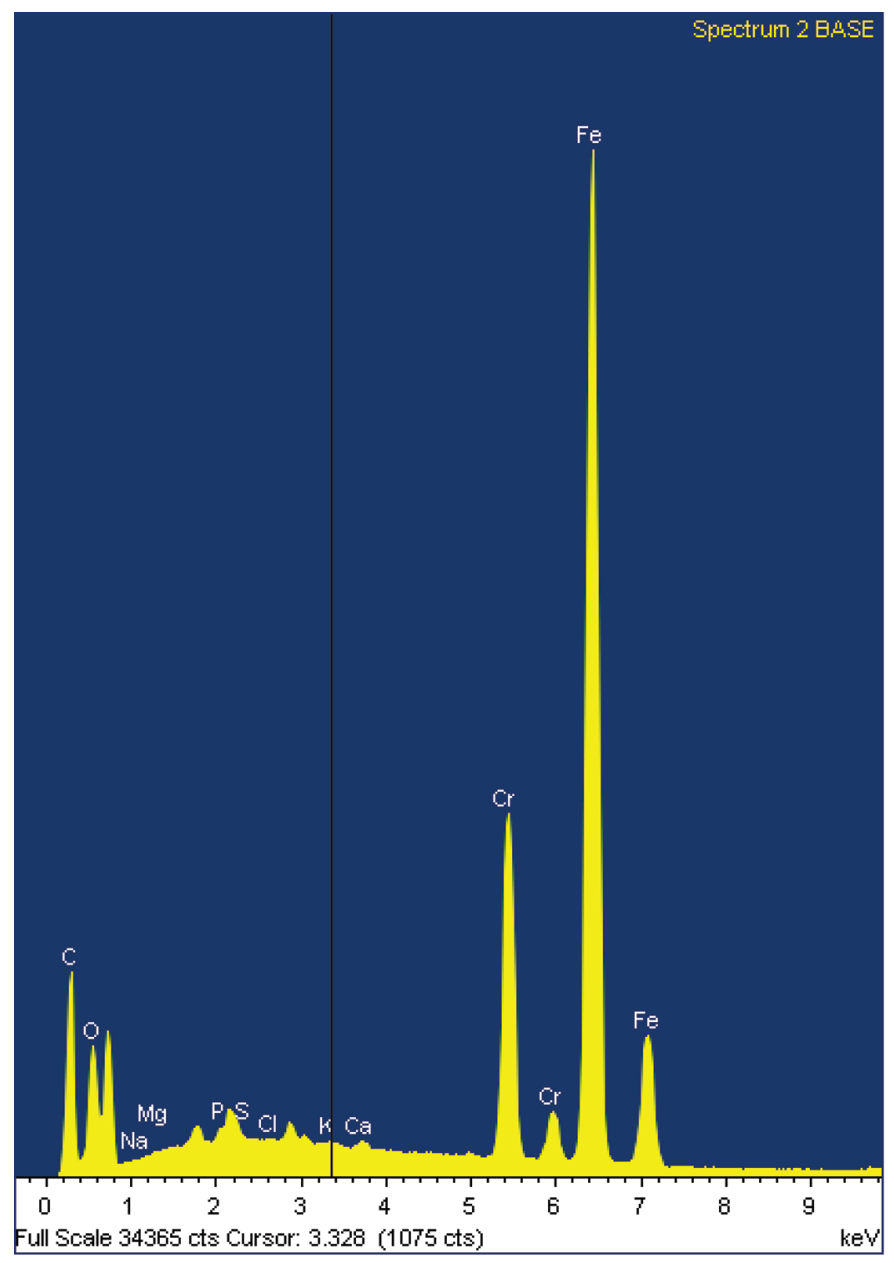

Figure 10. Results from energy-dispersive X-ray spectroscopy (EDX)-scanning electron microscopy. The scale expressed in kilo-electron volts $(\mathrm{keV})$ shows the signals obtained by EDX using an internal standard and identifying each peak with the corresponding element of the periodic table. Elements lighter than $\mathrm{C}$ are not shown by this technique. observed, respectively. The final mineral concentrations were $1.5 \times$ higher in the case of the chemical treatment compared with the enzymatic treatment, and they were more homogeneous in the case of the residues from the enzymatic treatment. The use of acid treatments after an alkaline treatment is useful for detaching the minerals by solubilization. However, if the adhesive element from the fouling is destroyed, which initiates the accumulation of matter on the surface, an effective mineral elimination can be achieved without using chemicals that have a high environmental impact (de Jong, 1997; Fryer and Asteriadou, 2009; Boyce et al., 2010). This is one of the advantages of the enzymatic treatments; it is not necessary to focus on all the elements, only on those that start the adhesion process and promote the accumulation of food residues.

\section{CONCLUSIONS}

Fluorescence microscopy and CLSM methods, in conjunction with microtopographic measurement using scanning electron microscopy-EDX and ICP-OES, are useful tools for understanding the composition, distribution, and structure of milk fouling matter adhered to surfaces. According to these methods, the organic composition of the fouling is different, depending on the depth of the layer studied. The protein and lipid contents are in the surface layer, whereas sugars are located in the innermost part. This distribution explains the process of the Maillard reaction, responsible for the start of fouling adhesion due to the presence of heat. The effectiveness of enzymatic cleaning of milk fouling was also found to be similar to that performed using a chemical product; however, as it is used at a lower temperature, the benefits of saving water and energy are significant. Moreover, after the enzymatic cleaning, a reduction occurs in the concentration of $\mathrm{Ca}$ and $\mathrm{P}$ compared with fouling intact. Thus, enzymatic cleaning, without the accumulation of $\mathrm{Na}$ from chemical cleaning, leaves an amount of mineral 1.5 times less than chemical cleaning. All of this information is very useful when studying deposits from the thermic milk treatments and when comparing the chemical and enzymatic cleaning formulas tested. Thus, the mixture of analytical techniques was used to obtain more information to support the argument for the advantages of using enzymes for cleaning this type of residue embedded in industrial surfaces.

\section{ACKNOWLEDGMENTS}

This work was supported by the European Union project FP7-KBBE-2013-7 (ENTHALPY). The authors have not stated any conflicts of interest. 
$\square \mathrm{Ca} \quad \mathrm{P} \quad \mathrm{K} \quad \mathrm{Na} \quad \mathrm{Mg}$

Mineral elements

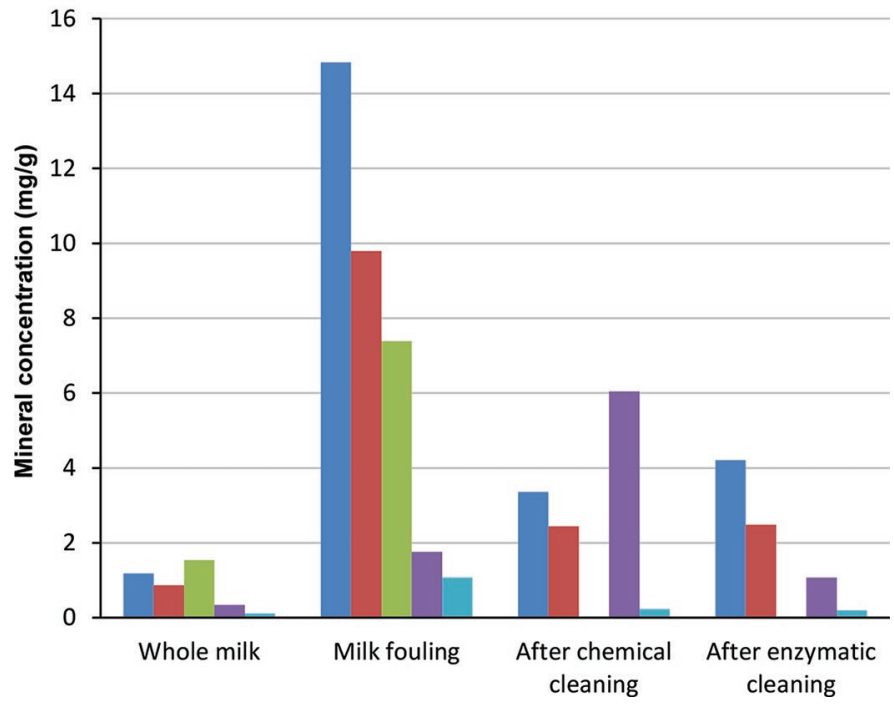

Figure 11. Inductively coupled plasma optical emission spectrometry results from whole milk, milk fouling models, as well as cleaning residues $(\mathrm{n}=10)$.

\section{REFERENCES}

Amjad, Z. 1998. Development of calcium phosphate inhibiting polymers for cooling water applications, Chapter 16. Pages 371-394 in Calcium Phosphates in Biological and Industrial Systems. Z. Amjad, ed. Kluwer Academic Publishers, Boston, MA.

Anonymous. 2015. Chemical disinfectants and antiseptics. Quantitative non-porous Surface test for the evaluation of bactericidal and/or fungicidal activity of chemical disinfectants used in food, industrial, domestic and institutional areas. Test method and requirements without mechanical action (phase 2/step 2). European Standard, EN 13697:2015.

Auty, M. A. E., M. Twomey, T. P. Guinee, and D. M. Mulvihill. 2001. Development and application of confocal scanning laser microscopy methods for studying the distribution of fat and protein in selected dairy products. J. Dairy Res. 68:417-427. https://doi.org/ 10.1017/S0022029901004873.

Ayala, N., A. Zamora, C. González, J. Saldo, and M. Castillo. 2017. Predicting lactulose concentration in heat-treated reconstituted skim milk powder using front-face fluorescence. Food Control 73:110-116. https://doi.org/10.1016/j.foodcont.2016.09.040.

Bansal, B., and X. D. Chen. 2006. A critical review of milk fouling in heat exchangers. Compr. Rev. Food Sci. Food Saf. 5:27-33. https: //doi.org/10.1111/j.1541-4337.2006.tb00080.x.

Barish, J. A., and J. M. Goddard. 2013. Anti-fouling surface modified stainless steel for food processing. Food Bioprod. Process. 91:352361. https://doi.org/10.1016/j.fbp.2013.01.003.

Boyce, A., A. V. Piterina, and G. Walsh. 2010. Assessment of the potential suitability of selected commercially available enzymes for cleaning-in-place (CIP) in the dairy industry. Biofouling 26:837850. https://doi.org/10.1080/08927014.2010.522705.

Bylund, G. 1995. Dairy processing handbook. Tetra Pak Processing Systems AB. Lund, Sweden.

Chiruta, J., K. R. Davey, and C. J. Thomas. 1997. Thermal inactivation kinetics of three vegetative bacteria as influenced by combined temperature and $\mathrm{pH}$ in a liquid medium. Food Bioprod. Process. 75:174-180. https://doi.org/10.1205/096030897531522. de Jong, P. 1997. Impact and control of fouling in milk processing. Trends Food Sci. Technol. 8:401-405. https://doi.org/10.1016/ S0924-2244(97)01089-3.

Doumèche, B., L. Galas, H. Vaudry, and P. Di Martino. 2007. Membrane foulants characterization in a drinking water production unit. Food Bioprod. Process. 85:42-48. https://doi.org/10.1205/ fbp06020.

Evers, J. M., R. G. Haverkamp, S. E. Holroyd, G. B. Jameson, D. D. S. Mackenzie, and O. J. McCarthy. 2008. Heterogeneity of milk fat globule membrane structure and composition as observed using fluorescence microscopy techniques. Int. Dairy J. 18:1081-1089. https://doi.org/10.1016/j.idairyj.2008.06.001.

Farias, E. L., K. J. Howe, and B. M. Thomson. 2014. Spatial and temporal evolution of organic foulant layers on reverse osmosis membranes in wastewater reuse applications. Water Res. 58:102-110. https://doi.org/10.1016/j.watres.2014.03.061.

Fryer, P. J., and K. Asteriadou. 2009. A prototype cleaning map: A classification of industrial cleaning processes. Trends Food Sci. Technol. 20:255-262. https://doi.org/10.1016/j.tifs.2009.03.005.

Fryer, P. J., P. T. Robbins, and K. Asteriadou. 2011. Current knowledge in hygienic design: Can we minimize fouling and speed cleaning? Procedia Food Sci. 1:1753-1760. https://doi.org/10.1016/j .profoo.2011.09.258.

Gandhi, G., J. K. Amamcharla, and D. Boyle. 2017. Effect of milk protein concentrate (MPC80) quality on susceptibility to fouling during thermal processing. Lebensm. Wiss. Technol. 81:170-179. https://doi.org/10.1016/j.lwt.2017.03.063.

González-Rivas, F., C. Ripolles-Avila, F. Fontecha-Umaña, A. G. Ríos-Castillo, and J. J. Rodríguez-Jerez. 2018. Biofilms in the spotlight: Detection, quantification, and removal methods. Compr. Rev. Food Sci. Food Saf. 17:1261-1276. https://doi.org/10.1111/ 1541-4337.12378.

Goode, K. R., J. Bowen, N. Akhtar, P. T. Robbins, and P. J. Fryer 2013. The effect of temperature on adhesion forces between surfaces and model foods containing whey protein and sugar. J. Food Eng. 118:371-379. https://doi.org/10.1016/j.jfoodeng.2013.03.016.

Graßhoff, A. 2002. Enzymatic cleaning of milk pasteurizers. Food Bioprod. Process. 80:247-252. https://doi.org/10.1205/ 096030802321154736

Guerrero-Navarro, A. E., A. G. Ríos-Castillo, C. Ripolles-Avila, A S. Hascoët, X. Felipe, and J. J. Rodríguez-Jerez. 2019. Development of a dairy fouling model to assess the efficacy of cleaning procedures using alkaline and enzymatic products. Lebensm. Wiss. Technol. 106:44-49. https://doi.org/10.1016/j.lwt.2019.02.057.

Hagsten, C., A. Altskär, S. Gustafsson, N. Lorén, L. Hamberg, F. Innings, M. Paulsson, and T. Nylander. 2016. Composition and structure of high temperature dairy fouling. Food Struct. 7:13-20. https://doi.org/10.1016/j.foostr.2015.12.002.

Huppertz, T., and I. Gazi. 2016. Lactose in dairy ingredients: Effect on processing and storage stability 1. J. Dairy Sci. 99:6842-6851. https://doi.org/10.3168/jds.2015-10033.

Jaeger, H., A. Janositz, and D. Knorr. 2010. The Maillard reaction and its control during food processing. The potential of emerging technologies. Pathol. Biol. (Paris) 58:207-213. https://doi.org/10 .1016/j.patbio.2009.09.016.

Liu, D. Z., S. Jindal, J. Amamcharla, S. Anand, and L. Metzger. 2017. Short communication: Evaluation of a sol-gel-based stainless steel surface modification to reduce fouling and biofilm formation during pasteurization of milk. J. Dairy Sci. 100:2577-2581. https:// doi.org/10.3168/jds.2016-12141.

Liu, W., P. J. Fryer, Z. Zhang, Q. Zhao, and Y. Liu. 2006. Identification of cohesive and adhesive effects in the cleaning of food fouling deposits. Innov. Food Sci. Emerg. Technol. 7:263-269. https://doi .org/10.1016/j.ifset.2006.02.006.

Newton, A. E., A. J. Fairbanks, M. Golding, P. Andrewes, and J. A. Gerrard. 2012. The role of the Maillard reaction in the formation of flavour compounds in dairy products - Not only a deleterious reaction but also a rich source of flavour compounds. Food Funct. 3:1231-1241. https://doi.org/10.1039/c2fo30089c. 
Parisi, S., and W. Luo. 2018. The importance of Maillard reaction in processed foods. Springer International Publishing, New York, NY. https://doi.org/10.1007/978-3-319-95463-9.

Ríos-Castillo, A. G., F. Fontecha-Umaña, and J. J. Rodríguez-Jerez. 2018. Long-term antibacterial efficacy of disinfectants based on benzalkonium chloride and sodium hypochlorite tested on surfaces against resistant gram-positive bacteria. Food Control 93:219-225. https://doi.org/10.1016/j.foodcont.2018.06.008.

Ríos-Castillo, A. G., F. González-Rivas, and J. J. Rodríguez-Jerez. 2017. Bactericidal efficacy of hydrogen peroxide-based disinfectants against gram-positive and gram-negative bacteria on stainless steel surfaces. J. Food Sci. 82:2351-2356. https://doi.org/10 $.1111 / 1750-3841.13790$.

Rosmaninho, R., and L. F. Melo. 2006. Calcium phosphate deposition from simulated milk ultrafiltrate on different stainless steel-based surfaces. Int. Dairy J. 16:81-87. https://doi.org/10.1016/j.idairyj .2005.01.006

Sadeghinezhad, E., S. N. Kazi, M. Dahari, M. R. Safaei, R. Sadri, and A. Badarudin. 2015. A comprehensive review of milk fouling on heated surfaces. Crit. Rev. Food Sci. Nutr. 55:1724-1743. https:// doi.org/10.1080/10408398.2012.752343.

Stoica, I. M., E. Vitzilaiou, H. Lyng Røder, M. Burmølle, D. Thaysen, S. Knøchel, and F. van den Berg. 2018. Biofouling on ROmembranes used for water recovery in the dairy industry. J. Water Process Eng. 24:1-10. https://doi.org/10.1016/j.jwpe.2018.05.004.
Timmerman, H., P. K. Mogensen, and A. Graßhoff. 2016. Enzymatic cleaning in food processing. Pages 555-568 in Handbook of Hygiene Control in the Food Industry. H. L. M. Lelieveld, J. Holah, and D. Gabrić, ed. Woodhead Publishing, Cambridge, MA. https: //doi.org/10.1016/b978-0-08-100155-4.00036-4

Visser, J., and T. J. M. Jeurnink. 1997. Fouling of heat exchangers in the dairy industry. Exp. Therm. Fluid Sci. 14:407-424. https://doi .org/10.1016/S0894-1777(96)00142-2.

Zhang, W., and L. Ding. 2015. Investigation of membrane fouling mechanisms using blocking models in the case of shear-enhanced ultrafiltration. Separ. Purif. Tech. 141:160-169. https://doi.org/10 .1016/j.seppur.2014.11.041.

Zouaghi, S., T. Six, N. Nuns, P. Simon, S. Bellayer, S. Moradi, S. G. Hatzikiriakos, C. André, G. Delaplace, and M. Jimenez. 2018. Influence of stainless steel surface properties on whey protein fouling under industrial processing conditions. J. Food Eng. 228:38-49. https://doi.org/10.1016/j.jfoodeng.2018.02.009.

\section{ORCIDS}

Abel Guillermo Ríos-Castillo @ https://orcid.org/0000-0002-9416-6479 José Juan Rodríguez-Jerez ำ https://orcid.org/0000-0001-7798-8529 